\title{
Oxidative changes in the blood and serum albumin differentiate rats with monoarthritis and polyarthritis
}

\author{
Adelar Bracht ${ }^{1}$, Sandra Silva Silveira ${ }^{1}$, Cristiane Vizioli Castro-Ghizoni ${ }^{1}$, Anacharis Babeto Sá-Nakanishi' \\ Márcia Rosângela Neves Oliveira² ${ }^{2}$ Ciomar Aparecida Bersani-Amado ${ }^{3}$, Rosane Marina Peralta ${ }^{1}$ \\ and Jurandir Fernando Comar ${ }^{1 *}$
}

*Correspondence:

jurandircomar@yahoo.com.br

${ }^{1}$ Department

of Biochemistry, State

University of Maringá,

Maringá 87020900, Brazil

Full list of author information

is available at the end of the

article

\begin{abstract}
Adjuvant arthritis in rats, as rheumatoid arthritis in humans, may be of greater or lesser severity, namely polyarthritis and monoarthritis, respectively. The present study was planned to evaluate the oxidative changes in the blood and specifically in the serum albumin of rats with adjuvant-induced mono- and poly-arthritis. Total antioxidant capacity, thiols, carbonyl groups, albumin, uric acid and ascorbic acid were measured in the total serum. The specific oxidative status of albumin was also measured after separation by affinity chromatography. All serum oxidative parameters were close to normal in monoarthritic rats with the exception of the ascorbic acid concentration, which was $23 \%$ lower, and albumin carbonyl groups, which were $64 \%$ higher. Many modifications were found in polyarthritic rats, specially the ascorbic acid concentration (35\% lower) and albumin carbonyl groups (102\% higher). The results revealed that the levels of ascorbic acid in the serum and carbonyl groups in the albumin molecule can be regarded as indicators of the severity of arthritis since they were modified by both monoarthritis and polyarthritis, but to different degrees.
\end{abstract}

Keywords: Chronic inflammation, Adjuvant-induced arthritis, Antioxidant status, Serum albumin oxidation

\section{Background}

Rheumatoid arthritis occurs in $0.5-1.0 \%$ of the adult population worldwide and in addition to the osteoarticular manifestations it is associated with an increased mortality rate, mainly due to cardiovascular complications (Uhlig et al. 2014; Kitas and Gabriel 2011; Gabriel and Michaud 2009). The pathophysiology of arthritis involves an intense hyperplasia of the articular cartilage with participation of proinflammatory cytokines and overproduction of reactive species in the synovium, such as superoxide anion $\left(\mathrm{O}_{2}^{-} \cdot\right)$, hydroxyl radical (HO.), hydrogen peroxide $\left(\mathrm{H}_{2} \mathrm{O}_{2}\right)$, and others, which act as mediators of tissue injury (Misko et al. 2013; Kundu et al. 2012; Filippin et al. 2008; Halliwell and Gutteridge 2007). Rheumatoid arthritis is a systemic disease and in addition to the joints other organs are affected (Mcinnes and Schett 2011; Sattar et al. 2003). The oxidative status is likewise changed in the serum blood of patients with rheumatoid arthritis and

(C) 2016 Bracht et al. This article is distributed under the terms of the Creative Commons Attribution 4.0 International License (http:// creativecommons.org/licenses/by/4.0/), which permits unrestricted use, distribution, and reproduction in any medium, provided you give appropriate credit to the original author(s) and the source, provide a link to the Creative Commons license, and indicate if changes were made. 
also in the liver, brain and vascular tissue of rats with adjuvant arthritis (Sarban et al. 2005; Kamanli et al. 2004; Lemarechal et al. 2006; Vasanthi et al. 2009; Seven et al. 2008; Taysi et al. 2002; Wendt et al. 2015; Comar et al. 2013; Haruna et al. 2007).

Rheumatoid arthritis may have a variable evolution, ranging from a mild and intermittent form to another more severe and progressive (Ohrndorf and Backhaus 2013). Similarly, periods of crisis (active arthritis) and remissions (inactive arthritis) are typical (Peluso et al. 2011). Several efforts have been made to correlate the oxidative state of blood and synovial fluid with the severity of the symptoms, activity of the disease, or even mortality rate (Datta et al. 2014; Stamp et al. 2012; Montecucco and Mach 2009; Nicholls and Hazen 2005). Although the reactive species are unstable, antioxidants and oxidation-modified proteins in the serum are more stable and may be a useful tool to correlate the serum oxidative status with the activity or severity of rheumatoid arthritis.

Carbonylation and nitration of amino acids are the most common oxidative modifications in serum proteins and uric acid, albumin and ascorbic acid are the major antioxidants components of the serum (Pavone et al. 2011; Matsuyama et al. 2009; Wayenberg et al. 2009; Kaur and Halliwell 1994; Turell et al. 2013; Yeum et al. 2004). Albumin alone accounts for approximately $70 \%$ of the serum antioxidant capacity (Taverna et al. 2013), which is attributed mainly to the sulfhydryl group (thiol) of cysteine 34 (Cys-34), the only thiol group of this protein (Fanali et al. 2012). About two-thirds of serum albumin contain the thiol group of Cys-34 in the reduced form, which correspond to approximately $80 \%$ of all serum thiol groups (Roche et al. 2008). Furthermore, albumin corresponds to more than $50 \%$ of all serum proteins and it is the only one that shows significant antioxidant activity (Taverna et al. 2013). In rheumatoid arthritis, the serum albumin thiol is more oxidized in arthritic patients than in healthy volunteers (Lemarechal et al. 2006; Banford et al. 1982) and the serum albumin levels fall in proportion to the severity of the disease (Cylmik et al. 2010).

Considering the oxidative changes in serum proteins, particularly albumin, and serum antioxidants in rheumatoid arthritis, as mentioned above, it is possible that the extension of these changes reflects different activities of the disease. Taking these hypotheses into consideration, the present work was planned to evaluate the oxidative status of both the serum and the albumin fraction of rats with adjuvant-induced arthritis with different degrees of severity. The latter is an experimental immunopathology in rats which shares many features of rheumatoid arthritis in humans and also presents prominent oxidative changes in the serum and synovial fluids of the animals (Pearson and Wood 1963; Bendele et al. 1999; Szekanecz et al. 2000; Arab and El-Sawalhi 2013; Nemirovskiy et al. 2009; Kogan et al. 2005).

Like rheumatoid arthritis, the adjuvant arthritis may also be of greater or lesser severity, depending on the dose of the adjuvant that is utilized inthe induction. The classical model, named polyarthritis, is induced by high doses of Freund's adjuvant and shows a strong and generalized inflammatory response, which affects multiple joints (five or more joints) (Donaldson et al. 1993; Bendele et al. 1999). On the other hand, it is also possible to induce a milder arthritis, known as monoarthritis, which is induced by a smaller dose of adjuvant and presents minor systemic effects and affects only one joint (Bracht et al. 2012; Donaldson et al. 1993). Thus, the present study aims to provide a detailed picture about the oxidative changes in the serum of rats with monoarthritis and 
polyarthritis and should also allow extrapolations for the serum of patients with greater or lesser severity of rheumatoid arthritis.

\section{Results}

\section{Characterization of the experimental model}

The weight of rats was monitored daily during a 18-day period after adjuvant injection and the weight gain is shown in Fig. 1. The mean of the initial weight of animals was $202 \pm 4.2 \mathrm{~g}$. The weight gain of monoarthritic rats was not different from that of the controls. Polyarthritic animals gained weight only slightly and initially, having returned to the same initial body weight at day $18(195 \pm 8.8 \mathrm{~g})$.

The development of inflammation was assessed by measuring the edema formation in the posterior paws. The results are shown in Fig. 2. The initial volume of the hind paw before the injection was $1.35 \pm 0.05 \mathrm{ml}$. An inflammatory reaction in the injected paw was observed on the first day post-adjuvant injection for both mono- and poly-arthritic rats (+90\%; panel a). This increase in the paw volume remained constant until the end of the experimental period (18 day) for monoarthritis. On the other hand, the volume of the injected paw of polyarthritic rats further increased progressively and on day 18 it was $81 \%$ greater than that of monoarthritic rats. The volume of the non-injected paw of both controls and monoarthritic animals did not change during the 18 days period (Fig. 2b). However, the inflammatory response in the non-injected paw started at day 10 for polyarthritic rats and progressed until day 18 ( $+84 \%$ compared to controls).

\section{Profile of serum proteins}

The serum protein profile was determined in the rats by means of cellulose acetate electrophoresis as well as the levels of plasma fibrinogen, a positive acute-phase protein, and serum transferrin, a negative acute-phase protein. Normally, serum cellulose acetate electrophoresis shows five protein bands, namely albumin, alpha-1, alpha-2, beta and gamma, as shown in Fig. 3. The total protein content was not different in controls, mono- and poly-arthritic rats. Furthermore, controls and monoarthritic rats presented

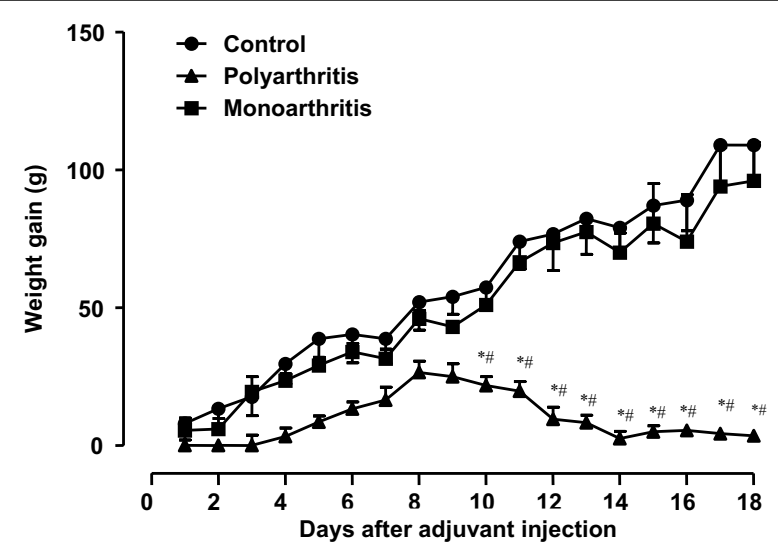

Fig. 1 Effects of Freund's adjuvant injection in Holtzman rats on body weight gain. Polyarthritis and monoarthritis were induced in rats as described in "Methods" section. The weights of the rats were monitored daily for 18 days after adjuvant injection. Each point represents the mean \pm SE of the mean of 3-4 animals. ${ }^{*} p<0.05$ indicates statistical difference from the controls and $\# p<0.05$ from the monoarthritic condition 

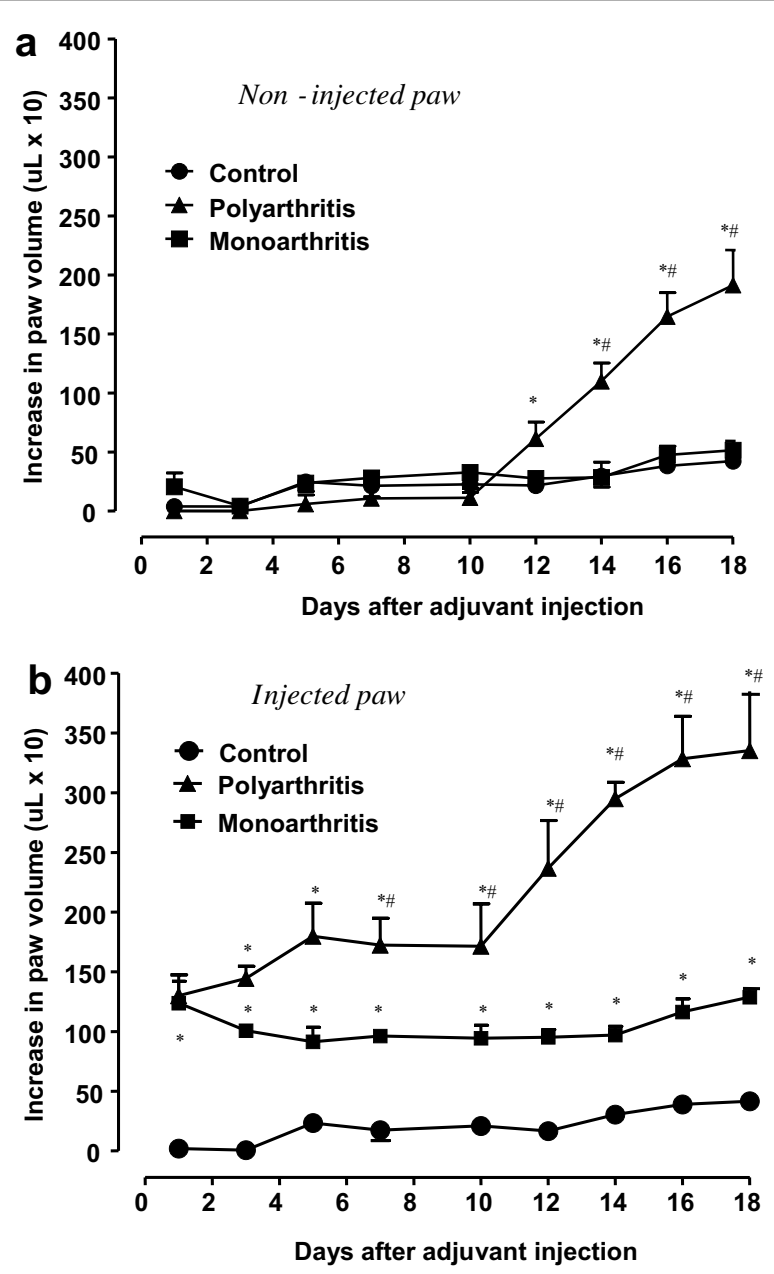

Fig. 2 Development of the inflammatory response to Freund's adjuvant in the posterior non-injected paw (a) and injected paw (b). Adjuvant arthritis was induced by injection of $0.1 \mathrm{ml}$ of Freund's adjuvant (inactivated $M$. tuberculosis) into the left hind paw. The concentrations of the injected suspension were $5.0 \mathrm{mg} \mathrm{ml}^{-1}$ for polyarthritis induction and $1.0 \mathrm{mg} \mathrm{ml}^{-1}$ for monoarthritis induction, as described in the "Methods" section. The volume of the paws was monitored daily by plethysmography and the results are expressed as the increase in paw volume. Each point represents the mean \pm SE of the mean of 3-4 animals. ${ }^{*} p<0.05$ indicates statistical difference from the controls and ${ }^{\#} p<0.05$ from the monoarthritic condition

the same protein bands. However, four protein bands were strongly modified by polyarthritis when compared to the control condition: albumin was $34 \%$ lower and alpha1, alpha- 2 and gamma were 500, 380 and $260 \%$ higher, respectively. Plasma fibrinogen levels were not different in control and monoarthritic rats, but they were $250 \%$ higher in polyarthritic rats (Table 1). Transferrin levels were only slightly higher in polyarthritic rats $(+15 \%$; Table 1$)$.

\section{Serum oxidative status}

Serum oxidative status was evaluated by means of its total antioxidant capacity (TAC), protein thiols groups and protein carbonyl groups. The results are shown in Table 2. The TAC is expressed only in concentration units $(\mu \mathrm{M})$, but the thiol and carbonyl groups are expressed as $\mu \mathrm{M}$ and, alternatively, as $\mathrm{nmol} \mathrm{mg}^{-1}$, since they are protein associated 


\section{a}

Control

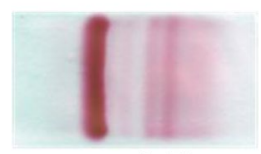

Monoarthritis

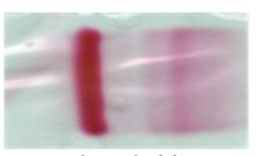

Polyarthritis
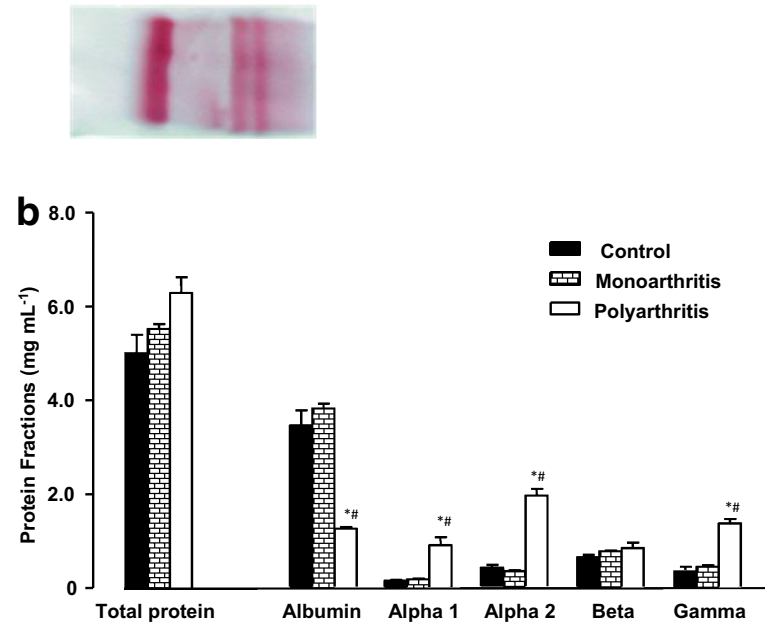

Fig. 3 Fractionation of the serum proteins by cellulose acetate electrophoresis. Cellulose acetate electrophoresis was performed with serum obtained from controls, mono- and poly-arthritic rats, as described in the "Methods" section. a Typical sample of dried electrophoresis strips for each experimental condition. b Levels of total proteins and electrophoretic bands obtained by densitometry of the dried strips. The results are expressed as $\mathrm{mg}$ protein $(\mathrm{ml} \text { serum })^{-1}$ and the values are the mean $\pm \mathrm{SE}$ of the mean of four animals for each experimental condition. ${ }^{*} p<0.05$ indicates statistical difference from the controls and ${ }^{\#} p<0.05$ from the monoarthritic condition

Table 1 Levels of serum transferrin and plasma fibrinogen in control, mono- and polyarthritic rats

\begin{tabular}{lrrr}
\hline Parameters & Groups & \\
\cline { 2 - 4 } & \multicolumn{1}{l}{ Control } & Monoarthritis & Polyarthritis \\
\hline Transferrin $\left(\mathrm{mg} \mathrm{dl}^{-1}\right)$ & $91.00 \pm 1.22$ & $103.8 \pm 3.32$ & $114.8 \pm 4.9^{*}$ \\
Fibrinogen $\left(\mathrm{mg} \mathrm{dl}^{-1}\right)$ & $1.88 \pm 0.14$ & $1.81 \pm 0.09$ & $6.56 \pm 1.23^{\#, *}$ \\
\hline
\end{tabular}

Blood was collected from the inferior cava vein and processed as described in the "Methods" section. Values are mean \pm SE of the mean of four animals for each experimental condition

${ }^{*} p<0.05$ indicates statistical difference from the controls and ${ }^{\#} p<0.05$ from the monoarthritic condition

parameters. The serum TAC was not different in control and monoarthritic rats, but it was $35 \%$ lower in polyarthritic rats. The serum thiol and carbonyl groups were also not different in control and monoarthritic rats. However, the serum thiol groups were $51 \%$ lower in the polyarthritic rats and the carbonyl groups were $40 \%$ higher in the polyarthritic rats when compared with the controls. 
Table 2 Total antioxidant capacity, levels of protein thiols and carbonyl groups in the serum of control, mono- and poly-arthritic rats

\begin{tabular}{|c|c|c|c|c|}
\hline \multirow[t]{2}{*}{ Parameter } & \multirow[t]{2}{*}{ Units } & \multicolumn{3}{|l|}{ Groups } \\
\hline & & Control & Monoarthritis & Polyarthritis \\
\hline Total antioxidant capacity & $\mu \mathrm{M}$ (eq. trolox) & $708.1 \pm 22.9$ & $712.2 \pm 40.4$ & $471.3 \pm 19.3^{\#, *}$ \\
\hline \multirow[t]{2}{*}{ Thiols groups } & $\mu \mathrm{M}$ & $230.9 \pm 5.8$ & $232.5 \pm 17.2$ & $118.8 \pm 10.8^{\#, *}$ \\
\hline & $\mathrm{nmol} \mathrm{mg}^{-1}$ protein & $4.41 \pm 0.18$ & $4.10 \pm 0.30$ & $2.33 \pm 0.21^{\#, *}$ \\
\hline \multirow[t]{2}{*}{ Carbonyl groups } & $\mu \mathrm{M}$ & $302.6 \pm 8.22$ & $327.8 \pm 14.2$ & $426.0 \pm 13.9^{\#, *}$ \\
\hline & $\mathrm{nmol} \mathrm{mg}^{-1}$ protein & $5.60 \pm 0.36$ & $5.91 \pm 0.30$ & $7.89 \pm 0.14^{\#, *}$ \\
\hline
\end{tabular}

The results of the total antioxidant capacity are expressed as $\mu \mathrm{mol} \mathrm{L}^{-1} \quad(\mu \mathrm{M})$ of trolox equivalents and the results of thiol and carbonyl groups are expressed as both $\mu \mathrm{M}$ and, alternatively, as $\mathrm{nmol}$ (mg protein) ${ }^{-1}$. Values are the mean $\pm \mathrm{SE}$ of the mean of four animals for each experimental condition

${ }^{*} p<0.05$ indicates statistical difference from the controls and ${ }^{\#} p<0.05$ from the monoarthritic condition

\section{Serum antioxidant components}

The albumin, uric acid and ascorbate together represent more than $90 \%$ of the total antioxidant activity of the serum (Erel 2004). Its levels are shown in Table 3. There was no difference in the levels of serum albumin between controls and monoarthritic rats, but polyarthritic rats presented lower serum albumin levels $(-34 \%)$. Serum uric acid was also not different between controls and arthritic animals, but it was $41 \%$ higher in the polyarthritic condition. The levels of serum ascorbic acid were 23 and $35 \%$ lower in mono- and poly-arthritic rats, respectively, when compared to the controls.

\section{Oxidative modifications in serum albumin}

The contribution of albumin molecule to the serum oxidative status was evaluated by means of carbonyl groups, thiol groups and antioxidant capacity. The results are shown in Table 4. The results are also shown as percentage of the albumin-associated parameters in relation to the total serum parameters. This allows inferring the albumin contribution for each parameter. The contribution of albumin to the TAC was similar for all experimental groups (between 75 and 80 \%). In absolute terms, the albumin antioxidant capacities of control and monoarthritic rats were not different, but that of polyarthritic animals was $34 \%$ lower. This corresponds to the exact percentage of the serum albumin decrease caused by polyarthritis. The albumin thiols contents of control and monoarthritic rats were not different and they correspond to approximately $80 \%$ of the serum total thiols for both conditions. In polyarthritic rats, however, the albumin thiols were

Table 3 The levels of serum antioxidant compounds in control, mono- and poly-arthritic rats

\begin{tabular}{lccr}
\hline Parameters & Groups & \\
\cline { 2 - 4 } & Control & Monoarthritis & Polyarthritis \\
\hline Albumin $(\mu M)$ & $328.8 \pm 10.6$ & $355.0 \pm 6.2$ & $218.2 \pm 8.9^{*, \#}$ \\
Uric acid $(\mu M)$ & $78.5 \pm 2.8$ & $72.4 \pm 6.3$ & $110.6 \pm 6.1^{*, \#}$ \\
Ascorbic acid $(\mu M)$ & $126.5 \pm 8.5$ & $98.2 \pm 4.5^{*}$ & $82.9 \pm 8.4^{*, \#}$ \\
\hline
\end{tabular}

Values are the mean $\pm S E$ of the mean of four animals for each experimental condition

${ }^{*} p<0.05$ indicates statistical difference from the controls and ${ }^{\#} p<0.05$ from the monoarthritics 
Table 4 Antioxidant capacity, thiol and carbonyl groups in the albumin molecule of control, mono- and poly-arthritic rats

\begin{tabular}{|c|c|c|c|c|}
\hline \multirow[t]{2}{*}{ Parameters } & \multirow[t]{2}{*}{ Units } & \multicolumn{3}{|l|}{ Groups } \\
\hline & & Control & Monoarthritis & Polyarthritis \\
\hline \multirow[t]{2}{*}{ Albumin antioxidant capacity } & $\mu \mathrm{M}$ (eq. trolox) & $563.3 \pm 52.0$ & $531.2 \pm 17.8$ & $377.0 \pm 7.0^{\#, *}$ \\
\hline & $\%$ of TAC & 80 & 75 & 80 \\
\hline \multirow[t]{3}{*}{ Albumin thiols groups } & $\mu \mathrm{M}$ & $188.7 \pm 9.2$ & $181.6 \pm 6.2$ & $85.1 \pm 6.2^{\#, *}$ \\
\hline & $\%$ total thiol & 82 & 78 & 71 \\
\hline & $\mathrm{nmol} / \mathrm{mg}$ albumin & $3.88 \pm 0.27$ & $3.33 \pm 0.22$ & $2.82 \pm 0.18^{*}$ \\
\hline \multirow[t]{3}{*}{ Albumin carbonyl groups } & $\mu \mathrm{M}$ & $92.3 \pm 6.4$ & $151.7 \pm 3.2^{*}$ & $186.1 \pm 7.6^{*, \#}$ \\
\hline & $\%$ total carbonyls & 30 & 36 & 36 \\
\hline & $\mathrm{nmol} / \mathrm{mg}$ albumin & $2.20 \pm 0.04$ & $2.78 \pm 0.13^{*}$ & $5.93 \pm 0.60^{\#, *}$ \\
\hline
\end{tabular}

The serum albumin separation was performed using affinity chromatography with Cibacron Blue $3 G^{\circledR}$ as described in the "Methods" section. The results are expressed in three ways: as $\mu \mathrm{M}$, as $\mathrm{nmol}$ ( $\mathrm{mg}$ albumin $)^{-1}$ and as the percentage of albumin parameters in relation to the total parameters before chromatography. Values are the mean $\pm \mathrm{SE}$ of the mean of 3-4 samples for each experimental condition

${ }^{*} p<0.05$ indicates statistical difference from the controls and ${ }^{\#} p<0.05$ from the monoarthritic condition

approximately $71 \%$ of the total thiols, and their absolute levels were $55 \%$ lower than those found in the controls.

The contribution of the albumin carbonyl groups to the total protein carbonyl groups can be best appreciated by examining Fig. 4 in conjunction with Table 4 . In spite of the fact that the albumin concentration was decreased only in polyarthritis, its relative contribution to the total carbonyl groups was somewhat increased by both mono- and polyarthritis (from 30 to $36 \%$; Table 4). This reflects the much more pronounced increase in the absolute contribution of albumin, whose carbonyl groups were 64 and $102 \%$ higher in mono- and poly-arthritic animals, respectively.

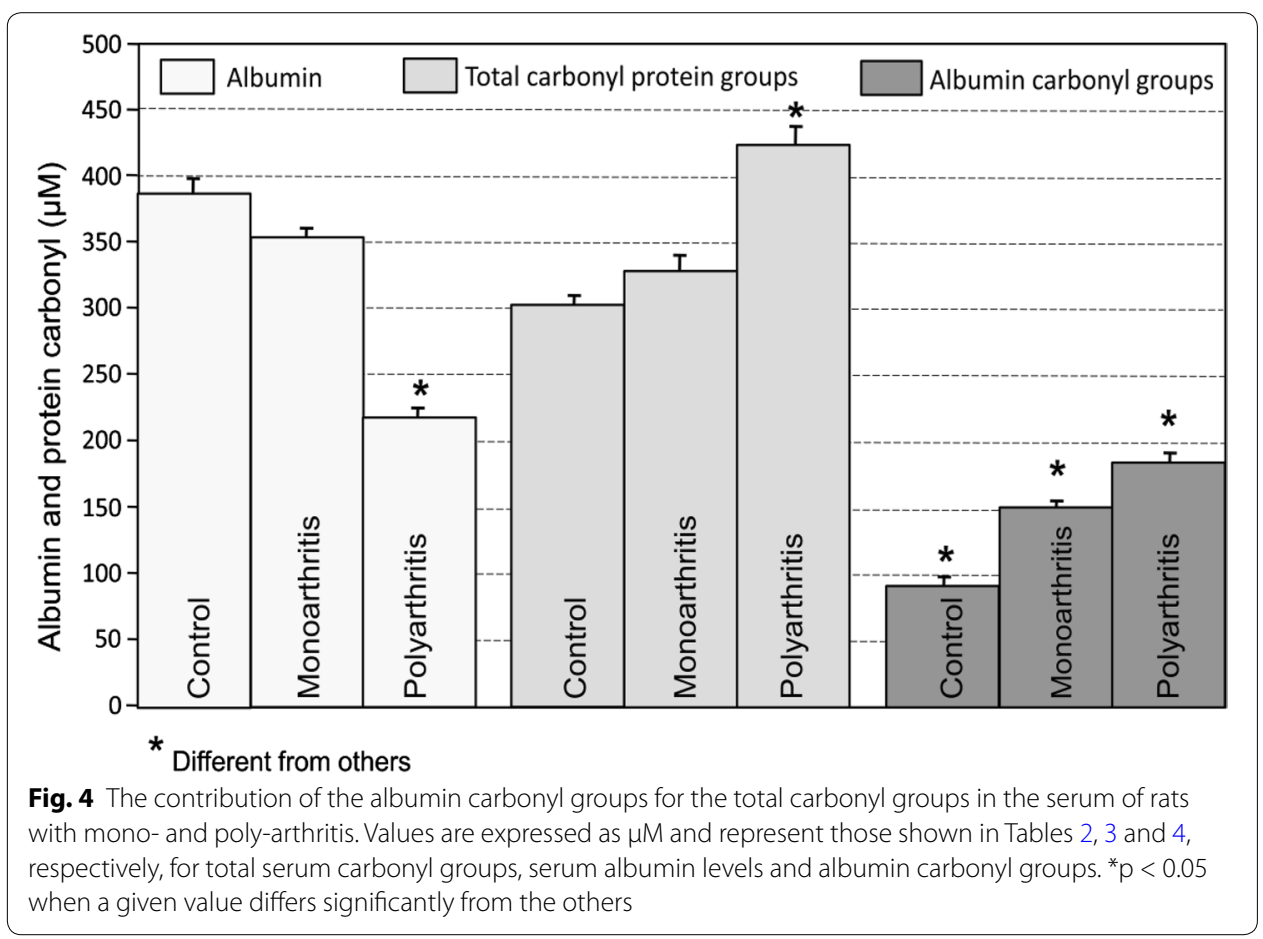




\section{Discussion}

Monoarthritis is considered a mild arthritis model in rats, which shows an inflammatory response in only one of the paws. Systemic effects are also present but normally mild, mainly changes in the liver metabolism (Bracht et al. 2012; Donaldson et al. 1993). The results of the present work showed that monoarthritic animals presented an inflammatory response that evolved only in the injected paw, but without weight loss and no changes of serum protein profile when compared to the controls. Thus, these parameters should be unsuitable for evaluating the systemic involvement of arthritis. On the other hand, polyarthritis is considered a severe arthritis model in rats, which shows a widespread inflammatory response, cachexia and systemic involvement (Comar et al. 2013; Donaldson et al. 1993). Our results showed that polyarthritic rats developed an intense inflammatory response also in the contralateral paw and furthermore strong changes in the serum protein profile: decreased albumin, increased globulins (alpha-1, alpha-2 and gamma bands) and increased plasma fibrinogen. The changes in the serum protein profile are mainly related with the induction of acute-phase proteins in the liver during systemic inflammation, which result in the increase in the levels of positive acute-phase proteins, such as fibrinogen, alpha- 2 macroglobulin, C-reactive proteins, complement factors and others. Concomitantly, a decrease in the levels of the negative acute-phase proteins occurs, especially albumin. Similar results regarding the serum protein pattern were already reported by previous work with both adjuvant-induced rats and exacerbated rheumatoid arthritis in humans (Rothkopf-Ischebeck 1980; Sharp et al. 1982). Thus, the serum protein profile that was characterized here, strongly correlates with severe arthritis, but it was not sensible enough to differentiate mild arthritis from the healthy state.

Concerning the oxidative state of the serum, protein carbonyl groups were assessed as pro-oxidant status markers and the TAC, thiol groups, albumin, uric acid and ascorbic acid as antioxidant status markers. Before discussing the observations about the oxidative status of the various experimental groups, two technical aspects deserve preliminary comments: (a) the difference between thiol groups and albumin levels as serum antioxidant parameters and (b) the components of the serum TAC. Concerning (a), it should be remarked that the levels of free cysteine and GSH are minimal in the serum and, consequently, the thiol groups present in significant amounts are practically only those associated to proteins (Moriarty-Craige and Jones 2004; Oettl and Stauber 2007). As previously reported, the cysteine-34 of the albumin is the main source of thiol groups in the serum (70-80 \%) and, thus, the antioxidant activity due to the serum thiol groups may be attributed mainly to albumin (Taverna et al. 2013). On the other hand, the serum thiol groups cannot be taken in place of albumin as an antioxidant parameter because other sites in this protein also react and sequestrate reactive species, mainly the six residues of methionine (Met-23, -87, -329, -298, -446 and -548) (Fanali et al. 2012). Thus, albumin is considered the main antioxidant in the serum but the thiol groups are only a portion of this larger antioxidant component. With reference to the TAC [point (b) above] it is usually expressed as $\mu \mathrm{M}$, similarly to the serum antioxidant constituents. However, it is important to note that this may not represent the sum of the individual antioxidant constituents because their reactions display different stoichiometries. The method used for the determination of the TAC is based on the capacity of the serum to 
neutralize the ABTS ${ }^{+}$radicals and the results are expressed as trolox equivalents (Erel 2004). One trolox molecule receives one pair of electrons, becoming able to neutralize two ABTS. ${ }^{+}$radicals. Thus, one equivalent of trolox represents one pair of electrons, but one equivalent of albumin may represent several electrons from many ABTS. ${ }^{+}$because it bears many antioxidant sites in the same molecule.

Returning to the effects of adjuvant arthritis on the serum oxidative status (Tables 2, 3 ), it is possible to note that, ascorbic acid was the only parameter whose concentration was found to be modified by monoarthritis. The ascorbic acid concentration, in principle at least, can be regarded as an indicator for monoarthritis in as much as polyarthritis caused a further drop in the ascorbic acid concentration, combined with substantial modifications in other parameters. It is important to mention, however, that the ascorbic acid levels may also fluctuate according to the nutritional status. This fact weakens substantially the role of the ascorbic acid concentration as an indicator of mild arthritis unless it is combined with another indicator as, for example, the albumin carbonyl groups (see next paragraph).

The oxidative status of the serum albumin was analyzed on terms of three parameters: its antioxidant capacity, the presence of thiol groups and the presence of carbonyl groups. These measurements allowed to evaluate the contribution of this protein to the oxidative state of the serum. Albumin was responsible for approximately $75-80 \%$ of the TAC and $80 \%$ of the total thiol groups in control and monoarthritic rats. Similar values were also reported for serum albumin in healthy humans (Taverna et al. 2013; Oettl and Stauber 2007). On the other hand, the albumin antioxidant capacity and the albumin thiol groups were lower in polyarthritic rats. The decreased albumin antioxidant capacity is more likely the consequence solely of the decrease in the albumin concentration because both diminished equally $(-34 \%)$. However, the albumin thiol groups in polyarthritis were approximately half that of the controls and, thus, are more likely the consequence of both the diminished serum albumin levels combined with more oxidized levels of the sulfhydryl groups. Although these two parameters strongly correlate with severe arthritis, they are obviously no indicators for monoarthritis because no significant differences were found between healthy and monoarthritic rats.

The albumin carbonyl groups were only $30-36 \%$ of the serum total carbonyl groups under all conditions, suggesting that the other serum proteins are equally or even more carbonylated than albumin. However, in absolute terms, the albumin carbonyl groups were significantly different in control, mono- and poly-arthritic rats. Thus, as ascorbic acid the serum albumin carbonyl groups may also be regarded as possible indicators of the severity of arthritis. Moreover, the changes in the serum levels of ascorbic acid and albumin carbonyl groups appeared in monoarthritis before the other systemic modifications that were evaluated here, such as the inflammatory response in the contralateral paw and the serum protein profile.

The results of the present work are in part innovative since they show that the levels of serum ascorbic acid and albumin carbonyl groups are differently changed in monoand poly-arthritic rats. Thus, these data may be added to others that were previously characterized for evaluating the activity of rheumatoid arthritis, such as the serum protein profile and the C-reactive protein (Rothkopf-Ischebeck 1980; Sharp et al. 1982) and should also allow extrapolations for the serum of patients with greater or lesser severity 
of rheumatoid arthritis. However, it is important to highlight some limitations of this work, which used only male rats. As rheumatoid arthritis is more frequent in females, new approaches using simultaneously male and female rats should be encouraged. This would allow to evaluate the effect of the gender on these oxidative parameters.

\section{Conclusion}

In summary, it can be said that the results of the present study revealed that (1) the serum oxidative state is strongly changed in the rats with adjuvant-induced polyarthritis; (2) both serum albumin levels and its oxidative state are also strongly changed by polyarthritis; (3) the levels of ascorbic acid and albumin carbonyl groups may be an useful indicator of the severity of rheumatoid arthritis in humans since they were different in control, mono- and poly-arthritic rats; and (4), the serum ascorbic acid concentration and the levels albumin carbonyl groups are quite sensitive indicators of mild arthritis since they appeared before other symptoms, such as systemic inflammation and modifications in the serum protein profile. If these findings are applicable or not to patients is a matter that depends on specific experiments at the clinical level that must demonstrate that the herein described oxidative changes also occur in rheumatoid arthritis.

\section{Methods}

\section{Chemicals}

Cibacron Blue 3G was purchased from GE Healthcare Life Sciences (São Paulo, SP, Brazil). Cellulose acetate strips for electrophoresis and cellulose membrane for dialysis were purchased from Inlab (Alamar Tecno-Científica Ltda, Diadema, Brazil). 6-Hydroxy2,5,7,8-tetramethylchroman-2-carboxylic acid (Trolox)and the complete Freund's adjuvant were purchased from Sigma Chemical Co (St Louis, MO, USA). Transferrin FS was purchased from DiaSys Diagnostic Systems GmbH (Holzheim, Germany). Commercial kits for the assay of albumin, uric acid and total proteins were purchased from Gold Analisa Diagnóstica Ltda (Belo Horizonte, MG, Brazil). All other chemicals were of analytical grade.

\section{Animals and treatments}

Male Holtzman rats weighing 180-210 g (about 50 days old) were used for induction of adjuvant arthritis. Polyarthritis was induced by injection in the left hind paw of $0.1 \mathrm{ml}$ of Freund's adjuvant containing $5.0 \mathrm{mg} \mathrm{ml}^{-1}$ of heat inactivated Mycobacterium tuberculosis, derived from the human strain H37Rv, suspended in mineral oil (Pearson and Wood 1963). Monoarthritis was induced in the same manner but with $0.1 \mathrm{ml}$ of Freund's adjuvant containing only $1.0 \mathrm{mg} \mathrm{ml}^{-1}$ of $M$. tuberculosis (Sigma-Aldrich, St Louis, MO, USA) (Bracht et al. 2012). Rats of similar ages served as controls. After 18 days of the adjuvant injection, rats were selected for the experiments. All procedures were done in accordance with the world-wide accepted ethical guidelines for animal experimentation and previously approved by the Ethics Committee for Animal Experimentation of the University of Maringá (Protocol 094/2013-CEEA). 


\section{Blood collection and preparation}

Rats fasted for $12 \mathrm{~h}$ were anesthetized with intraperitoneal injection of sodium pentobarbital (50 mg kg-1) and the peritoneal cavity was surgically exposed. Blood was then collected from the cava vein and poured in tubes either with $110 \mathrm{mM}$ sodium citrate (BD vacutainer tube ${ }^{\circledR}$ ) for plasma or without anticoagulant for serum. After centrifugation at $3000 \mathrm{~g}$ for $10 \mathrm{~min}$, the supernatant was separated as serum or plasma fraction.

\section{Profile of serum proteins}

Protein electrophoresis was performed with cellulose acetate strips $(2.5 \times 14 \mathrm{~cm}$; Cellogel Electrophoresis Co.) and protein fractions were quantified by densitometry. Briefly, the cellulose acetate strips were previously soaked for $10 \mathrm{~min}$ into $60 \mathrm{mM}$ sodium barbital buffer $(\mathrm{pH}$ 8.6) and thereafter placed on the bridge of a horizontal electrophoresis tank. Then, the serum was applied on each strip at the cathodal end, a $3.0 \mathrm{~mA}$ current was applied at $250 \mathrm{~V}$ and electrophoresis was run for $30 \mathrm{~min}$. After electrophoresis the strips were soaked into Ponceau $\mathrm{S}$ red dye for $10 \mathrm{~min}$ and destained with glacial acetic acid. The strips were dried on a kiln at $70{ }^{\circ} \mathrm{C}$ and the quantification of the electrophoretic bands was made with a densitometer (CELM DS-3 $5^{\circledR}$ ) on blue filter for Ponceau S.

The serum transferrin was measured by immunoturbimetry and the values expressed as $\mathrm{mg} \mathrm{dl}^{-1}$. The fibrinogen was measured in the plasma by coagulometry using a commercial kit (TriniClot ${ }^{\mathrm{TM}}$ Fibrinogen Kit) and the results expressed as $\mathrm{mg} \mathrm{dl}^{-1}$. Total proteins and albumin levels were measured spectrophotometrically using commercial kits.

\section{Purification of serum albumin}

Each sample consisted of a serum pool that was obtained from three animals and the albumin separation was performed by affinity chromatography as described previously (Guerin-Dubourg et al. 2012). Briefly, the affinity column of Cibacron Blue $3 G^{\circledR}$ was built on a plastic syringe $(1.3 \mathrm{~cm}$ of diameter and $8.2 \mathrm{~cm}$ of height), where the gel was packed to a final volume of $10 \mathrm{ml}$. The column was then equilibrated with $50 \mathrm{mM}$ Tris $-\mathrm{HCl}$ buffer ( $\mathrm{pH} \mathrm{7.4)}$ and $4.0 \mathrm{ml}$ of serum sample was applied. After, the column was washed with TRIS- $\mathrm{HCl}$ buffer. In this process, albumin is retained and the other proteins are eluted. The albumin was then eluted with $1.5 \mathrm{M} \mathrm{NaCl}$, which was dialyzed with cellulose membrane (12-16 kDa of cut-off and $25 \AA$ of porosity) against 0.1 M PBS buffer (pH 7.4) at $4{ }^{\circ} \mathrm{C}$ for $24 \mathrm{~h}$ under gentle agitation. The dialysate was adjusted to a final volume of $5.0 \mathrm{ml}$ with PBS buffer for measuring thiol groups, carbonylated proteins and albumin.

\section{Total antioxidant capacity (TAC)}

The TAC of the serum was measured by spectrophotometry using 2,2'-azino-bis(3etylbenzthiazoline-6-sulphonic acid) or ABTS (Erel 2004). The antioxidant activity was calculated from the standard curve prepared with trolox (6-hydroxy-2,5,7,8-tetrametylchloraman-2-carboxylic acid), a water-soluble analog of vitamin $\mathrm{E}$, and the results were expressed as nmol ( $\mathrm{ml}$ serum $)^{-1}$.

\section{Total and albumin carbonyl and sulfhidryl groups (thiols)}

The thiol content was measured by spectrophotometry (412 nm) using DTNB (5,5'-dithiobis 2-nitrobenzoic acid) and the contents were calculated using the molar extinction 
coefficient $(\varepsilon)$ of $1.36 \times 10^{4} \mathrm{M}^{-1} \mathrm{~cm}^{-1}$ (Faure and Lafond 1995). The protein carbonyl groups contents were measured by spectrophotometry $(370 \mathrm{~nm})$ using 2,4-dinitrophenylhydrazine (DNPH) and the contents were calculated using the molar extinction coefficient $(\varepsilon)$ of $2.2 \times 10^{4} \mathrm{M}^{-1} \mathrm{~cm}^{-1}$ (Levine et al. 1990). The values of both carbonyl and thiol groups were expressed as nmol of carbonyl/thiol groups (ml serum $)^{-1}$ or, alternatively, $\mathrm{nmol}(\text { mg protein) })^{-1}$.

\section{Ascorbic acid and uric acid}

Uric acid was measured by an enzymatic method using commercial kits (Gold Analisa ${ }^{\circledR}$ ) and the results were expressed as $\mathrm{mg}(\mathrm{ml} \text { serum })^{-1}$. Ascorbic acid was measured by spectrophotometry $(520 \mathrm{~nm})$ with the 2,4-DNPH-thiourea-CuSO $\mathrm{C}_{4}$ (DTC) reagent (Omaye et al. 1979). The contents were calculated using a standard curve prepared with ascorbic acid and the expressed as $\mathrm{mg}(\mathrm{ml} \text { serum })^{-1}$.

\section{Statistical analysis}

The error parameters presented in graphs and tables are standard errors of the means. Statistical analysis was done by means of the GraphPad Prism Software (version 5.0). The statistical significance was analyzed by means of one-way ANOVA and the Newman-Keuls multiple comparisons test was applied with the $5 \%$ level $(\mathrm{p}<0.05)$.

\section{Authors' contributions}

JFC conceived and designed the experiments. SSS, ABSN and CVCG performed the experiments of oxidative state. MRNO performed the experiments of the serum protein profile. CABA induced and provided the animals with adjuvant arthritis. RMP and SSS performed the albumin separation by chromatography. JFC and AB analyzed and interpreted the data. JFC wrote the paper and $A B$ reviewed the paper. All authors have read and approved the final manuscript.

\section{Author details}

${ }^{1}$ Department of Biochemistry, State University of Maringá, Maringá 87020900, Brazil. ${ }^{2}$ Department of Clinical Analysis, State University of Maringá, Maringá 87020900, Brazil. ${ }^{3}$ Department of Pharmacology and Therapeutics, State University of Maringá, Maringá 87020900, Brazil.

\section{Acknowledgements}

Authors wish to thank the financial support of the Coordenação de Aperfeiçoamento de Pessoal de Nivel Superior (CAPES) and of the Conselho Nacional de Desenvolvimento Científico e tecnológico (CNPq).

\section{Competing interests}

The authors declare that they have no competing interests.

Received: 14 December 2015 Accepted: 5 January 2016

Published online: 15 January 2016

\section{References}

Arab HH, El-Sawalhi MM (2013) Carvedilol alleviates adjuvant-induced arthritis and subcutaneous air pouch edema: modulation of oxidative stress and inflammatory mediators. Toxicol Appl Pharmacol 268:211-218

Banford JC, Brown DH, Hazelton RA, McNeil CJ, Smith WE, Sturrock RD (1982) Altered thiol status in patients with rheumatoid arthritis. Rheumatol Int 2:107-111

Bendele AM, McComb J, Gould T, McAbee T, Sennelle G, Chlipala E, Guy M (1999) Animal models of arthritis: relevance to human disease. Toxicol Pathol 27:134-142

Bracht L, Barbosa CP, Caparroz-Assef SM, Cuman RKN, Ishii-Iwamoto EL, Bracht A, Bersani-Amado CA (2012) Effects of simvastatin, atorvastatin, ezetimibe, and ezetimibe + simvastatin combination on the inflammatory process and on the liver metabolic changes of arthritic rats. Fund Clin Pharmacol 26:722-734

Comar JF, Sá-Nakanishi AB, Oliveira AL, Wendt MMN, Bersani-Amado CA, Ishii-Iwamoto EL, Peralta RM, Bracht A (2013) Oxidative state of the liver of rats with adjuvant-induced arthritis. Free Radic Biol Med 58:144-153

Cylmik B, Chrostek L, Gindzienska-Sieskiewicz E, Sierakowski S, Szmitkowski M (2010) Relationship between serum acutephase proteins and high disease activity in patients with rheumatoid arthritis. Adv Med Sci 55:80-85

Datta S, Kundu S, Ghosh P, De S, Ghosh A, Chatterjee M (2014) Correlation of antioxidant status with oxidative tissue in patients with rheumatoid arthritis. Clin Rheumatol 33:1557-1564

Donaldson LF, Seckl JR, McQueen DS (1993) A discrete adjuvant-induced monoarthritis in the rat: effects of adjuvant dose. J Neurosci Methods 49:5-10 
Erel O (2004) A novel automated direct measurement method for total antioxidant capacity using a new generation, more stable ABTS radical cation. Clin Biochem 37:277-281

Fanali G, Di Masi A, Trezza V, Marino M, Fasano M, Ascenzi P (2012) Human serum albumin: from bench to bedside. Mol Aspect Med 33:209-290

Faure P, Lafond JL (1995) Measurement of plasma sulphidryl and carbonyl groups as a possible indicator of protein oxidation. In: Favier AE, Kadet J, Kakyanaraman B, Fontecave M, Pierre JL (eds) Analysis of free radicals in biological systems. Birkhauser Verlag, Basel, pp 238-247

Filippin LI, Vercelino R, Marroni NP, Xavier RM (2008) Redox signaling and the inflammatory response in rheumatoid arthritis. Clin Exp Immunol 152:415-422

Gabriel SE, Michaud K (2009) Epidemiological studies in incidence, prevalence, mortality, and comorbidity of the rheumatic diseases. Arthritis Res Ther 11:229-245

Guerin-Dubourg A, Catan A, Bourdon E, Rondeau P (2012) Structural modifications of human albumin in diabetes. Diabetes Metab 38:171-178

Halliwell B, Gutteridge JMC (2007) Free radicals in biology and medicine. Oxford University Press, London

Haruna Y, Morita Y, Yada T, Satoh M, Fox DA, Kashihara N (2007) Fluvastatin reverses endothelial dysfunction and increased vascular oxidative stress in rat adjuvant-induced arthritis. Arthritis Rheum 56:1827-1835

Kamanli A, Naziroglu M, Aydilek N, Hacievliyagil C (2004) Plasma lipid peroxidation and antioxidant levels in patients with rheumatoid arthritis. Cell Biochem Funct 22:53-57

Kaur H, Halliwell B (1994) Evidence for nitric oxide-mediated oxidative damage in chronic inflammation nitrotyrosine in serum and synovial fluid from rheumatoid patients. FEBS Lett 350:9-12

Kitas GD, Gabriel SE (2011) Cardiovascular disease in rheumatoid arthritis: state of the art and future perspectives. Ann Rheum Dis 70:8-14

Kogan G, Stasko A, Baurenová K, Polovka M, Soltés L, Brezová V, Navarová J, Mihalová D (2005) Antioxidant properties of yeast ( $1 \rightarrow 3$ )- $\beta$-D-glucan studied by electron paramagnetic resonance spectroscopy and its activity in the adjuvant arthritis. Carbohydr Polym 61:18-28

Kundu S, Ghosh P, Datta S, Ghosh A, Chattopadhyay S, Chatterjee M (2012) Oxidative stress as a potential biomarker for determining disease activity in patients with rheumatoid arthritis. Free Radic Res 46:1482-1489

Lemarechal H, Allanore Y, Chenevier-Gobeaux C, Kahan A, Ekindjian OG, Borderie D (2006) Serum protein oxidation in patients with rheumatoid arthritis and effects of infliximab therapy. Clin Chim Acta 372:147-153

Levine RL, Garland D, Oliver CN, Amici A, Climent I, Lenz AG, Ahn BW, Shaltiel S, Stadtman ER (1990) Determination of carbonyl content in oxidatively modified proteins. Methods Enzymol 186:464-478

Matsuyama Y, Terawaki H, Terada T, Era S (2009) Albumin thiol oxidation and serum protein carbonyl formation are progressively enhanced with advancing stages of chronic kidney disease. Clin Exp Nephrol 13:308-315

McInnes IB, Schett G (2011) The pathogenesis of rheumatoid arthritis. N Engl J Med 365:2205-2209

Misko TP, Radabaugh MR, Highkin M, Abrams M, Friese O, Gallavan R, Bramson C, Hellio Le Graverand MP, Lohmander LS, Roman D (2013) Characterization of nitrotyrosine as a biomarker for arthritis and joint injury. Osteoarthr Cartil 21:151-156

Montecucco F, Mach F (2009) Common inflammatory mediators orchestrate pathophysiological processes in rheumatoid arthritis and atherosclerosis. Rheumatology 48:11-22

Moriarty-Craige SE, Jones DP (2004) Extracellular thiols and thiol/disulfide redox in metabolism. Annu Rev Nutr 24:481-509

Nemirovskiy OV, Radabaugh MR, Aggarwal P, Funckes-Shippy CL, Mnich SJ, Meyer DM, Sanyer T, Mathews WR, Misko TP (2009) Plasma 3-nitrotyrosine is a biomarker in animal models of arthritis: pharmacological dissection of iNOS' role in disease. Nitric Oxide 20:150-156

Nicholls SJ, Hazen SL (2005) Myeloperoxidase and cardiovascular disease. Arterioscler Thromb Vasc Biol 25:1102-1111

Oettl K, Stauber RE (2007) Physiological and pathological changes in the redox state of human serum albumin critically influence its binding properties. Br J Pharmacol 151:580-590

Ohrndorf S, Backhaus M (2013) Advances in sonographic scoring of rheumatoid arthritis. Ann Rheum Dis 72:ii69-ii75

Omaye ST, Ternbull JD, Sauberlich HE (1979) Selected methods for the determination of ascorbic acid in animal cells, tissues, and fluids. Methods Enzymol 62:3-11

Pavone B, Sirolli V, Giardinelli A, Bucci S, Forli F, Di Cesari M, Sacchetta P, Di Pietro N, Pandolfi A, Urbani A, Bonomini M (2011) Plasma protein carbonylation in chronic uremia. J Nephrol 24:453-464

Pearson CM, Wood FD (1963) Studies of arthritis and other lesions induced in rats by the injection of mycobacterial adjuvant. VII. Pathologic details of the arthritis and spondylitis. Am J Pathol 42:73-95

Peluso G, Michelutti A, Bosello S, Gremese E, Tolusso B, Ferraccioli G (2011) Clinical and ultrasonographic remission determines different changes of relapse in early and long standing rheumatoid arthritis. Ann Rheum Dis 70:172-175

Roche M, Rondeau P, Singh NR, Tarnus E, Bourdon E (2008) The antioxidant properties of serum albumin. FEBS Lett 582:1783-1787

Rothkopf-Ischebeck M (1980) Differentiation of various experimentally-induced pathological processes in Wistar rats by serum protein electrophoresis using cellulose-acetate membranes. Lab Anim 14:153-165

Sarban S, Kocyigit A, Yazar M, Isikan UE (2005) Plasma total antioxidant capacity, lipid peroxidation and erythrocyte antioxidant enzyme activities in patients with rheumatoid arthritis and osteoarthritis. Clin Biochem 38:981-986

Sattar N, McCarey DW, Capell H, Mclnnes IB (2003) Explaining how "high-grade" systemic inflammation accelerates vascular risk in rheumatoid arthritis. Circulation 108:2957-2963

Seven A, Guzel S, Aslan M, Hamuryudan V (2008) Lipid, protein, DNA oxidation and oxidant status in rheumatoid arthritis. Clin Biochem 41:538-543

Sharp JP, Lidsky MD, Duffy J (1982) Clinical responses during gold therapy for rheumatoid arthritis. Changes in synovitis, radiologically detectable erosive lesions, serum proteins, and serologic abnormalities. Arthritis Rheum 25:540-549

Stamp LK, Khalilova I, Tarr JM, Senthilmhan R, Turner R, Haigh RC, Winyard PG, Kettle AJ (2012) Myeloperoxidase and oxidative stress in rheumatoid arthritis. Rheumatology 51:1796-1803 
Szekanecz Z, Halloran MM, Volin MV, Woods JM, Strieter RM, Haines GK, Kunkel SL, Burdick MD, Koch AE (2000) Temporal expression of inflammatory cytokines and chemokines in rat adjuvant-induced arthritis. Arthritis Rheum 43:1266-1277

Taverna M, Marie AL, Mira JP, Guidet B (2013) Specific antioxidant properties of human serum albumin. Ann Intensive Care 3:4-10

Taysi S, Polat F, Gul F, Sari RA, Bakan E (2002) Lipid peroxidation, some extracellular anti-oxidants, and anti-oxidant enzymes in serum of patients with rheumatoid arthritis. Rheumatol Int 21:200-204

Turell L, Radi R, Alvarez B (2013) The thiol pool in human plasma: the central contribution of albumin to redox processes. Free Radic Biol Med 65:244-253

Uhlig T, Moe RH, Kvien TK (2014) The burden of disease in rheumatoid arthritis. Pharmacoeconomics 32:841-851

Vasanthi P, Nalini G, Rajasekhar G (2009) Status of oxidative stress in rheumatoid arthritis. Int J Rheum Dis 12:29-33

Wayenberg JL, Ransy V, Vermeylen D, Damis E, Botari SP (2009) Nitrated plasma albumin as a marker of nitrative stress and neonatal encephalopathy in perinatal asphyxia. Free Radic Biol Med 47:975-982

Wendt MMN, Sá-Nakanishi AB, Ghizoni CVC, Bersani-Amado CA, Peralta RM, Bracht A, Comar JF (2015) Determination of oxidative stress in the brain of rats with adjuvant-induced arthritis. Exp Mol Pathol 98:549-557

Yeum KJ, Russell RM, Krinsky NI, Aldini G (2004) Biomarkers of antioxidant capacity in the hydrophilic and lipophilic compartments of human plasma. Arch Biochem Biophys 430:97-103

\section{Submit your manuscript to a SpringerOpen ${ }^{\circ}$ journal and benefit from:}

- Convenient online submission

- Rigorous peer review

- Immediate publication on acceptance

- Open access: articles freely available online

- High visibility within the field

- Retaining the copyright to your article

Submit your next manuscript at $\boldsymbol{\nabla}$ springeropen.com 